\title{
Membangun Word Of Mouth Melalui Adaptive Selling Customer Owned Loyalty Dan Loyalty To The Service Provider (Studi kasus pada Mahasiswa Fakultas Ekonomi Universitas Sarjanawiyata Tamansiswa)
}

\author{
M. Riziq Agung1 \\ Universitas Sarjanawiyata Tamansiswa \\ e-mail: m.riziqagung@gmail.com \\ Ida Bagus Nyoman Udayana ${ }^{2}$ \\ Universitas Sarjanawiyata Tamansiswa \\ e-mail: ibn.udayana@yahoo.co.id
}

\begin{abstract}
This research aims to find out the effect of adaptive selling on word of mouth through salesperson owned loyalty and loyalty to the service provider at Hotel Respatih Kasih.This research uses a quantitative approach. Accidental purposive sampling technique. Based on sampling techniques, a sample of 100 people was obtained. The data analysis test tool used in this study used Bergandan Regression Test.The results showed that adaptive selling variables positively influenced custumer owned loyalty, custumer owned loyalty variable positively influencedLoyalty to the Service Provider, Variable Custumer owned loyalty positively influenced Word of Mouth, and variable Loyalty to the Service Provider positively influenced Word of Mouth.
\end{abstract}

Keywords: Word Of Mouth, Adaptive Selling Customer, Loyalty

\begin{abstract}
Abstrak
Penelitian ini bertujuan mengetahui pengaruh adaptive selling yang terdapatpadaword of mouth melalui Custumer owned loyalty dan loyalty to the service provider pada Hotel Respatih Kasih.Penelitian ini menggunakan pendekatan kuantitatif. Teknik accidental purposive sampling. Berdasarkan teknik pengambilan sampel, maka didapat sampel sebanyak 100 orang. Alat uji analisis data yang dipakai dalam penelitian ini dengan memakai Uji Regresi Berganda. Hasil penelitian menunjukkan bahwa variabel Adaptive selling berpengaruh positif terhadap Custumer owned loyalty, variabel Custumer owned loyalty berpengaruh positif terhadap Loyalty to the Service Provider, variabel Custumer owned loyalty berpengaruh positif terhadap Word of Mouth, dan variabel Loyalty to the Service Provider berpengaruh positifterhadap Word of Mouth.
\end{abstract}

Kata Kunci : Word Of Mouth, Adaptive Selling Customer, Loyalty

\section{A. Pendahuluan}

Pengaruh globalisasi mengakibatkan industri jasa yang terdiri dari bemacammacam industri seperti industri telekomunikasi, perbankan, transportasi dan

\footnotetext{
${ }^{1}$ Mahasiswa Prodi Manajemen, FakultasEkonomi Universitas Sarjanawiyata Tamansiswa Yogyakarta

2 Mahasiswa Prodi Manajemen, FakultasEkonomi Universitas Sarjanawiyata Tamansiswa Yogyakarta
} 
perhotelan yang berkembang begitu cepat. Sulastiyono ${ }^{3}$ menyatakan Industri hotel adalah suatu jenis akomodasi yang mempergunakan salah satu atau seluruh bangunan untuk mengadakan jasa penginapan, makanan, dan minuman, serta jasa penunjangan lainnya bagian umumnya yang dikelola komersial. Kotler dan Amstrong ${ }^{4}$ mengartikan jasa sebagai suatu aktivitas yang bermanfaat yang ditawarkan oleh satu pihak lain yang pada dasarnya tanpa wujud dan tidak menghasilkan kepemilikan apapun.

Pada dahulunya fungsi perhotelan hanya sebagai tempat beristirahat bagi masyarakat yang melakukan perjalanan bisnis atau masyarakat yang sedang berlibur/berwisata dan tidak memiliki relasi ditempat tujuan. Namun dengan berkembangnyakeadaan, urgensi hotel mengalamiperkembangan. Sulastiyono mendefinisikan hotel ialah usaha komersial yang mempersiapkan tempat untuk menginap, makan dan pelayanan-pelayanan lain untuk masyarakat baik secara pribadi maupun umum. Sekarang, banyak hotel digunakan untuk acara seperti rapat perusahaan, pernikahan, launching untuk produk baru suatu perusahaan dan tak jarang juga hotel digunakan untuk sarana menghabiskan waktu berliburnya teruntuk kalangan masyarakat yang memiliki ekonomi menengah atas.

Adaptive selling penjualan yang mengadaptasi pada kebutuhan dan harapan pelanggan selama penjual dan pelanggan saling berinteraksi. Adaptive selling juga merupakan pembaruan system komunikasi, format komunikasi dan isi pesan selama berinteraksi yang dilakukan antara penjual dan pembeli. Praktek adaptive selling memungkinkan tenaga penjual untuk mempromosikan keunggulan personal selling. Adaptive selling diartikan sebagai perubahan perilaku selama penjualan ataupun setelah terjadinya komunikasi terhadap pelanggan yang dilakukan berdasarkan pada informasi yang diperoleh mengenai keadaan penjualan ${ }^{5}$.

Dampakpositif adaptive sellingpadakinerja penjualan telah banyak diteliti. Penelitian yang dilakukan Morganet al, , membuktikan bahwa penerapan adaptive selling membukktikan bahwa mampu meningkatkan tenaga kinerja penjual. Kemampuan paling mendasar yang butuhkan oleh pertemuan penjualan ialah kemampuan tenaga penjual untuk dapat merasakan dan menerima informasi dari pembeli dan lingkungannya. Oleh sebabitu adaptive selling bergantung tidak hanya pada kemampuan perseptual tetapi juga kemampuan kognitif. Signifikasi loyalitas pelanggan

\footnotetext{
${ }^{3}$ Agus, Sulastiyono. Manajemen Penyelanggaraan Hotel, 2011), h.6

${ }^{4}$ Kotler, Amstrong. Prinsip-prinsip Pemasaran, 2004), h 73-72

${ }^{5}$ Morgan, C.T., King, R.A., Weisz, J.R., \&Schopler. Introduction to psychology, 1986), h.144
} 
sangat berkaitan dengan kelangsungan perusahaan dan terhadap kuatnya pertumbuhan dan perkembangan perusahaan di masa yang akan datang. Oleh karena itu, mempertahankan pelanggan atau konsumen yang ada pada saat ini berpengaruh sangat penting dibanding dengan adanya strategi agresif seperti memperluas ukuran pasar dengan menggaet konsumen potensial ${ }^{6}$.

Perilaku tenaga penjualan dipengaruhi oleh orientasi nilai-nilai yang dimilikinya. Tenaga penjual memiliki pekerjaan yang mentargetkan hasil tertentu dan pencapaian target ini akan mempengaruhi status dan reward yang akan diperolehnya pada lingkungan pekerjaan. Berhubungan dengan hal inilah maka orientasi nilai individu yang dimaksud dalam penelitian ini merupakan orientasi kinerja. Adanya orientasi nilai membuatnya ingin dinilai memiliki kemampuan lebih dan mau mempertimbangkan hasil akhir yang dicapai sebagai bukti terhadap kemampuannya7.

Loyalitas pelanggan juga dapat terbentuk dari kepuasan yang dirasakan pelanggan. Kotler ${ }^{8}$ mendiskripsikan kepuasan ialah perasaan senang atau kecewa seseorang yang muncul setelah membandingan kinerja (atau hasil) produk yang dipikirkan terhadap kinerja (atau hasil) yang diharapkan. Selain itu, nilainilai yang dipikirkan konsumen juga akan memberikan pengaruh terhadap keloyalan seorang konsumen pada produk atau jasa yang digunakannya. Nilai-nilai yang dipikirkan pelanggan adalah selisih antara evaluasi calon konsumen atas semua manfaat serta semua biaya tawaran tertentu dan alternatif - alternatif lain yang dipikirkan.

Informasi dari mulut ke mulut ialah merupakan petukaran informasi baik positif maupun negative yang dilakukan secara informal antar individual mengenai suatu jasa atau produk. Informasi dari mulut ke mulut dapat dijadikan sebagai kekuatan bagi konsumen yang puas maupun konsumen yang tidak puas. Konsumen yang puas cenderung menghasilkan informasi dari mulut ke mulut secara positif. Kepuasan konsumen seringkali dikaitkan dengan evaluasi yang menyeluruh dari konsumen yang cenderung dapat berdampak atau mempengaruhi perilaku konsumen terhadap kualitas jasa atau produk sehingga dapat membantu perusahaan berupa komunikasi dari mulut ke mulut yang positif.

Dalam masyarakat, berkembang salah satu bentuk komunikasi pemasaran yaitu word of mouth (WOM). Word of mouth ialah merupakan bentuk pujian, rekomendasi,

\footnotetext{
${ }^{6}$ Lupiyoadi dan Hamdani. Manajemen Pemasaran jasa, 2006), h.195

${ }^{7}$ Sujan et al. Learning Orientation, Working, and Efective Selling, 1994), h.134

${ }^{8}$ Kotler, Philip. Prinsip-Prinsip Pemasaran. 2008), h.177
} 
ataupun komentar konsumen mengenai sekitar pengalaman pelanggan atas layanan jasa atau produk yang sangat- sangat mempengaruhi keputusan konsumen atau perilaku pembelian pelanggan. Word of Mouth (WOM) disebabkan ketika pelanggan berbicara kepada orang lain mengenai pengalamannya tentang suatu produk, merek, layanan atau perusahaan tertentu kepada perusahan lain ${ }^{9}$. Beberapa pemasar menilai rendah promosi seperti ini, karena seringkali promosi ini dianggap membutuhkan opinion leaders (pendapat pemimpin) yang sulit ditemui. Selain itu Word of mouth ini cenderung lebih sulit dikontrol dan tidak terbatas.

Bermacam-macam fasilitas-fasilitas dan layanan hotel Respatih Kasih untuk menjamin kenyamanan pelanggan yang sudah disediakan namun masih juga terdapat keluhan dari para pelanggan pengguna jasa hotel ini di setiap tahunnya. Definisi dari keluhan adalah suatu ungkapan atau pernyataan rasa kurang puas terhadap satu produk atau layanan, baik secara lisan maupun tulisan, dari pelanggan internal maupun eksternal. Publikasi Tingkat Penghunian Kamar Hotel Daerah Istimewa Yogyakarta 2018 diterbitkan setiap tahun oleh Badan Pusat Statistik Provinsi Daerah Istimewa Yogyakarta. Data yang ditampilkan berasal dari responden usaha hotel, baik yang berbintang maupun nonbintang yang dikumpulkan setiap bulan. Hotel dengan klasifikasi bintang dicacah secara lengkap (sensus), sedangkan hotel nonbintang dicacah secara sampel survei. Jumlah responden sebanyak 288 hotel, terdiri dari 143 hotel bintang dan 145 hotel non bintang.

Aktivitas pariwisata di Daerah Istimewa Yogyakarta meliputi wisata MICE (Meeting, Incentive, Convention and Exhibition), wisata budaya, wisata alam, wisata minat khusus, dan berbagai fasilitas pariwisata lainnya, seperti resort, hotel, dan restoran. Tercatat ada 143 hotelbintang dan 1475 hotel nonbintang di Daerah Istimewa Yogyakarta pada 2018. Jumlah tamu yang datang dan menginap pada tahun 2018 mengalami penurunan sebesar 4,80 persen dibanding tahun sebelumnya. Pada 2018 tercatat kunjungan wisatawan yang menginap di hotel sebanyak 6525894 orang terdiri dari 282278 orang wisatawan mancanegara dan 6243616 orang wisatawan nusantara. Dari sejumlah wisatawan yang datang sebanyak 63,67 persen menginap di hotelbintang. Selebihnya sebanyak 36,33 persen menginap pada hotel nonbintang. Ratarata lama menginap tamu pada hotel bintang mencapai 1,66 malam. Sedangkan ratarata lama menginap tamu pada hotel nonbintang mencapai 1,43 malam. Tingkat

\footnotetext{
${ }_{9}^{9}$ Arbaniah, Siti. Studi Customer Loyalty (WOM) Positif Pada Bisnis Ritel Pasar Modern. 2010), h. 89-90.
} 
Penghunian Kamar (TPK) pada hotel bintang sebesar 57,24 persen. Lebih tinggi 28,99 poin jika dibandingkan TPK hotel nonbintang hanya sebesar 28,25 Berdasarkan beberapa uraian diatas maka dengan ini penulisan melakukan penelitian dengan judul "Membangun Word of Mouth Melalui Custumer Owned Loyalty dan Loyalty to The Service Provider Pada Hotel Respatih Kasih".

\section{B. Landasan Teori}

\section{Adaptive selling}

Adaptive selling merupakan penjualan yang mengadaptasi pada kebutuhan dan harapan pelanggan selama penjualan dan pelanggan saling berinteraksi ${ }^{10}$. Adaptive selling juga merupakan pemodifikasian gaya komunikasi, format presentasi dan isi pesan yang dilakukan oleh penjual selama berinteraksi dengan pembeli.

\section{Loyalty To The Service Provider}

Loyalitas yang diberikan penjual atas layanan yang di berikan merupakan aspek penting dari loyalitas pelanggan. Loyalitas yang diberikan tenaga penjual sangat penting bagi perusahaan atau entitas, hal ini karena pelanggan memiliki anggapan awal bahwa perusahaan memiliki loyalitas dalam penyediaan layanan ${ }^{11}$.

\section{Customer Owner Loyalty}

Loyalitas adalah pilihan yang dilakukan konsumen untuk membeli merek tertentu dibandingkan merek yang lain didalam katagori produk ${ }^{12}$. Loyalitas pelanggan dideskripikan sebagai pelanggan puas terhadap produk atau merek yang dikonsumsi atau dipakai, dan akan membeli ulang produk tersebut ${ }^{13}$.

\section{Word Of Mouth}

Malau ${ }^{14}$ menjelaskan bahwa word of mouth communication atau komunikasi ucapan mulut sering dilakukan pelanggan untuk mendapat informasi tentang produk atau jasa melalui temannya dengan cara memperhatikan temannya memakai dan menggunakan produk tersebut serta berbagai informasi secara langsung dari mulut ke mulut .

\footnotetext{
${ }_{10}$ Morgan, C.T., King, R.A., Weisz, J.R., \& Schopler. Introduction to psychology. 1986). 145-146

${ }^{11}$ Chen, Z. X. and Francesco, A. M. Employee demography, organizational commitment, and turnover intentions in China: Do cultural differences matter. 2014), h. 6.

12 Nugroho, Farid Yuniar. Pengaruh Citra Merek dan Kepuasan Pelanggan Terhadap Loyalitas Konsumen, 2011), h.16

${ }^{13}$ Sumarwan, U. Perilaku Konsumen: Teori dan Penerapan dalam Pemasaran, 2011), h.75-76

14 Malau, Harman. Manajememn Pemasaran. CV Alfabeta. Bandung, 2017: 292.
} 


\section{Kerangka Pemikiran Dan Pengembangan Hipotesis}

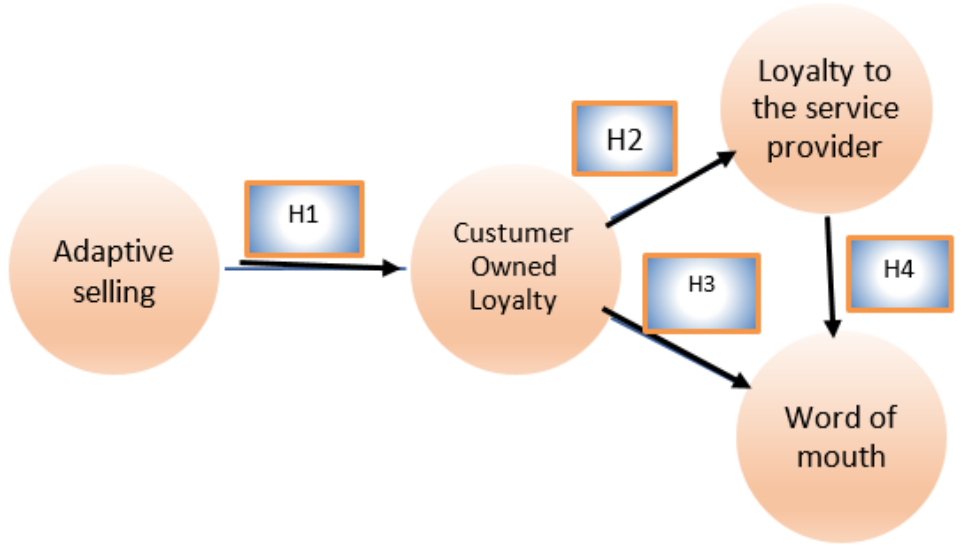

Gambar 1.Kerangka Pikir

Berdasarkan kerangka piker gambar 1 atas, maka dapat ditarik hipotesis dalam penelitian sebagai berikut:

H1: Ada pengaruh positif dansignifikan dariadaptive selling capabilityterhadap kinerja penjualan

H2:Custumer owned loyalty berpengaruh positif dan signifikan terhadap loyality to the service provider nasabah.

H3:Custumer owned loyalty berpengaruh positif dan signifikan terhadap Word Of Mouth pelanggan pada konsumen Hotel Respatih Kasih Yogyakarta.

H4: Loyality To The Service Provider berdampak positif dan signifikan terhadap Word of Mouth pada konsumen Hotel Respatih Kasih Yogyakarta.

\section{Metode Penelitian}

1. Sifat Penelitian

Penelitian ini menggunakan penelitian kuantitatif. Metode kuantitatif berupa angka-angka yang berasal dari pengukuran dengan menggunakan skala terhadap variabel-variabel yang ada dalam penelitian ${ }^{15}$.

2. Populasi dan Sampel

Populasi adalah sekumpulan data yang memiliki karakteristik sama menjadikan objek yang memiliki kualitas yang sesuai dengan apa yang telah ditetapkan oleh peneliti. Populasi dalam penelitian adalah seluruh tamu Hotel Respati Kasih.Sampel adalah sebagian dari populaasi yang dapat mewakili dan mencerminkan secara keseluruhan dari populasi yang akan diteliti. Sampel dalam penelitian ini adalah tamu Hotel Respati Kasih sebanyak 100 orang.

\section{Teknik Analisis Data}

Analisis data pada penelitian ini terdiri dari Analisis Deskriptif, Uji Asumsi Klasik (Uji Normalitas, Uji Multikolonieritas, Uji Heteroskedastisitas), UjiRegresiBerganda, dan Uji Hipotesisdenganpengujiansecara parsial menggunakan

\footnotetext{
${ }^{15}$ Sugiyono, Metode Penelitian Pendidikan Pendekatan Kuantitatif, Kualitatif, dan R\&D., 2018), h.80-142
} 
uji t dan secara simultan menggunakan uji F, serta pengujian Koefisien Determinasi (R2).

\section{Hasil Penelitian}

\section{Statistik Deskriptif}

a. Usia Pelanggan Hotel Respatih Kasih

Berdasarkan hasil penelitian, dapat dideskripsikan karakteristik responden berdasarkan usia pelanggan Hotel Respatih Kasih Yogyakarta yaitu sebagai berikut:

Tabel 1 Berdasarkan Usia

\begin{tabular}{|c|l|r|r|r|r|}
\hline \multicolumn{2}{|c|}{} & Frequency & Percent & $\begin{array}{c}\text { Valid } \\
\text { Percent }\end{array}$ & $\begin{array}{c}\text { Cumulative } \\
\text { Percent }\end{array}$ \\
\hline \multirow{5}{*}{ Valid } & $\begin{array}{l}17-25 \\
\text { Tahun }\end{array}$ & 43 & 43,0 & 43,0 & 43,0 \\
\cline { 2 - 6 } & $\begin{array}{l}>26 \\
\text { Tahun }\end{array}$ & 57 & 57,0 & 57,0 & 100,0 \\
\cline { 2 - 6 } & Total & 100 & 100,0 & 100,0 & \\
\hline
\end{tabular}

Sumber : Lampiran 3

Berdasarkan tabel 1 dapat diketahui bahwaumur responden yang berusia 17 sampai dengan 25 tahun yakni sebanyak 43 orang, responden yang berusia 26 tahun keatas sebanyak 57 orang. Berdasarkan hasil tersebut maka dapat dinyatakan bahwa mayoritas responden pada penelitian ini berusia 26 tahun keatas yakni sebanyak 57 orang ( $57,0 \%)$.

b. Jenis Kelamin Pelanggan Hotel Respatih Kasih Yogyakarta

Berdasarkan hasil penelitian, dapat dideskripsikan karakteristik responden berdasarkan status pernikahan pelanggan Legend Coffee Yogyakarta yaitu sebagai berikut:

Tabel 2. Jenis Kelamin

\begin{tabular}{|r|l|r|r|r|r|}
\hline \multicolumn{2}{|c|}{ Jenis Kelamin } \\
\hline \multicolumn{2}{|c|}{} & $\begin{array}{c}\text { Frequen } \\
\text { cy }\end{array}$ & $\begin{array}{c}\text { Percen } \\
\text { t }\end{array}$ & $\begin{array}{c}\text { Valid } \\
\text { Percent }\end{array}$ & $\begin{array}{c}\text { Cumulative } \\
\text { Percent }\end{array}$ \\
\hline \multirow{3}{*}{ Valid } & Laki - Laki & 52 & 52,0 & 52,0 & 52,0 \\
\cline { 2 - 6 } & Perempuan & 48 & 48,0 & 48,0 & 100,0 \\
\cline { 2 - 6 } & Total & 100 & 100,0 & 100,0 & \\
\hline
\end{tabular}

Sumber : lampiran 3

Berdasarkan tabel 2, dapat diketahui bahwa karakteristik responden berdasarkan jenis kelamin pelanggan Hotel Respatih Kasih Yogyakarta yaitu responden berjenis kelamin laki-laki sebanyak 52 orang dan perempuan sebanyak 48 orangsehingga dapat disimpulkan bahwa sebagian besar adalah responden berjenis kelamin laki-laki sebanyak 52 responden (52,0\%).

c. Karakteristik berdasarkan Lama Menginap Pelanggan Hotel Respatih Kasih Yogyakarta

Berdasarkan hasil penelitian, dapat dideskripsikan karakteristik responden berdasarkan lama menginap pelanggan Hotel Respatih Kasih Yogyakarta yaitu sebagai berikut:

Tabel 3 Lama Menginap

\begin{tabular}{|l|l|l|l|l|}
\hline \multicolumn{5}{|c|}{ Lama Menginap } \\
\hline & Freque & Percent & Valid & Cumulativ \\
\hline
\end{tabular}


M. Riziq Agung, Ida Bagus : Membangun Word Of Mouth ....

\begin{tabular}{|l|l|r|r|r|r|}
\hline \multicolumn{2}{|c|}{} & \multicolumn{1}{|c|}{ ncy } & & \multicolumn{1}{c|}{ Percent } & e Percent \\
\hline \multirow{4}{*}{ Valid } & 1 Malam & 47 & 47,0 & 47,0 & 47,0 \\
\cline { 2 - 6 } & 2 Malam & 37 & 37,0 & 37,0 & 84,0 \\
\cline { 2 - 6 } & $>3$ Malam & 16 & 16,0 & 16,0 & 100,0 \\
\cline { 2 - 6 } & Total & 100 & 100,0 & 100,0 & \\
\hline
\end{tabular}

Sumber : Lampiran 3

Berdasarkan tabel 3, dapat diketahui bahwa karakteristik responden berdasarkan lama menginap pelanggan Hotel Respatih Kasih Yogyakarta yaitu menginap satu malam sebanyak 47 orang, dua malam sebanyak 37 orang, tiga malam keatas sebanyak 16 orang jadi dapat dinyatakan bahwa sebagian besar adalah responden dengan lama menginap satu malam yaitu sebanyak 47 responden $(47,0 \%)$.

\section{Uji Asumsi Klasik}

\section{a. Uji Normalitas}

Uji ini adalah untuk menguji apakah pengamatan berdistribusi secara normal atau tidak, uji ini mengunakan kolmogorov smirnov. Hasil uji Normalitas dapat dilihat pada tabel dibawah ini.

Pengaruh Adaptive Selling Terhadap Sales Owned Loyality

Tabel 4 Uji Normalitas

One-Sample Kolmogorov-Smirnov Test

\begin{tabular}{|l|l|r|}
\hline \multicolumn{2}{|l|}{} & $\begin{array}{c}\text { Unstandar } \\
\text { dized } \\
\text { Residual }\end{array}$ \\
\hline $\mathrm{N}$ & Mean & 100 \\
\cline { 2 - 3 } $\begin{array}{l}\text { Normal } \\
\text { Parameters }\end{array}$ & Std. & 1,8948205 \\
& Deviation & 8 \\
\hline \multirow{2}{*}{$\begin{array}{l}\text { Most Extreme } \\
\text { Differences }\end{array}$} & Absolute &, 065 \\
\cline { 2 - 3 } & Positive &, 045 \\
\cline { 2 - 3 } & Negative &,- 065 \\
\hline Kolmogorov-Smirnov Z &, 653 \\
\hline Asymp. Sig. (2-tailed) &, 787 \\
\hline \multicolumn{2}{|l|}{ a. Test distribution is Normal. } \\
\hline \multicolumn{2}{|l|}{ b. Calculated from data. } \\
\hline
\end{tabular}

Sumber : Lampiran 3

Pengaruh Sales Owned Loyality Terhadap Loyality to the Service Provider

Tabel 5 Uji Normalitas

\begin{tabular}{|l|l|r|}
\hline \multicolumn{2}{|c|}{ One-Sample Kolmogorov-Smirnov Test } \\
\hline \multicolumn{2}{|c|}{} & $\begin{array}{c}\text { Unstandar } \\
\text { dized } \\
\text { Residual }\end{array}$ \\
\hline $\mathrm{N}$ & Mean & 100 \\
\hline \multirow{2}{*}{$\begin{array}{l}\text { Normal } \\
\text { Parameters }\end{array}$} & $\begin{array}{l}\text { Std. } \\
\text { Deviation }\end{array}$ & 1,7635776 \\
\hline Most Extreme & Absolute & 7 \\
\hline
\end{tabular}


M. Riziq Agung, Ida Bagus : Membangun Word Of Mouth ....

\begin{tabular}{|c|c|c|}
\hline \multirow[t]{2}{*}{ Differences } & Positive & ,063 \\
\hline & Negative &,- 047 \\
\hline \multicolumn{2}{|c|}{ Kolmogorov-Smirnov Z } & ,627 \\
\hline \multicolumn{2}{|c|}{ Asymp. Sig. (2-tailed) } & ,827 \\
\hline \multicolumn{3}{|c|}{ a. Test distribution is Normal. } \\
\hline
\end{tabular}

Sumber : Lampiran 3

\section{Pengaruh Sales Owned Loyality dan Loyality to the Service Provider Terhadap} Word of Mouth

Tabel 6 Uji Normalitas

\begin{tabular}{|l|l|r|}
\hline \multicolumn{2}{|c|}{ One-Sample Kolmogorov-Smirnov Test } \\
\hline \multicolumn{2}{|l|}{} & $\begin{array}{c}\text { Unstandar } \\
\text { dized } \\
\text { Residual }\end{array}$ \\
\hline $\mathrm{N}$ & Mean & 100 \\
\cline { 2 - 3 } $\begin{array}{l}\text { Normal } \\
\text { Parameters }\end{array}$ & $\begin{array}{l}\text { Std. } \\
\text { Deviation }\end{array}$ &, 0000000 \\
\hline \multirow{2}{*}{$\begin{array}{l}\text { Most Extreme } \\
\text { Differences }\end{array}$} & Absolute &, 051 \\
\cline { 2 - 3 } & Positive &, 051 \\
\cline { 2 - 3 } Negative &,- 048 \\
\hline Kolmogorov-Smirnov Z &, 509 \\
\hline Asymp. Sig. (2-tailed) &, 958 \\
\hline \multicolumn{2}{|l|}{ a. Test distribution is Normal. } \\
\hline \multicolumn{2}{|l}{ b. Calculated from data. } \\
\hline
\end{tabular}

Berdasarkan tabel 4, 5, dan 6 dapat diketahui Adaptiveselling terhadap Salesperson Ownde loyalty nilai asymp.sig sebesar 0,787>0,05 jadi dapat disimpulkan bahwa data berdistribusi normal. Selanjutnya pada tabel 4.12 Salesperson Ownde loyalty terhadap Loyality To The Service Provider dapat diketahui nilai asymp. sig sebesar 0,827>0,05 jadi dapat disimpulkan bahwa data berdistribusi normal. Serta pada tabel 4.13 Salesperson Ownde loyalty dan Loyality To The Service Provider terhadap word of mouth dapat diketahui nilai asymp.sig sebesar 0,957> 0,05 sehingga dapat dinyatakan bahwa data berdistribusi normal.

\section{b. Uji Heteroskedastisitas}

Berikut tabel dan hasil signifikan dari uji heteroskedasitisitas, yang menggambarkan ada atau tidaknya heteroskedastisitas dalam model penelitian:

Pengaruh Adaptive Selling Terhadap Sales Owned Loyality Tabel 7

Uji Glejser Heteroskedastisitas

\begin{tabular}{|c|c|c|c|c|}
\hline \multicolumn{5}{|c|}{ Coefficients $^{\mathbf{a}}$} \\
\hline \multirow{2}{*}{ Model } & $\begin{array}{c}\text { Unstandardized } \\
\text { Coefficients }\end{array}$ & $\begin{array}{c}\text { Standardized } \\
\text { Coefficients }\end{array}$ & $\mathrm{t}$ & $\mathrm{S}$ \\
$\mathrm{i}$
\end{tabular}


M. Riziq Agung, Ida Bagus : Membangun Word Of Mouth ....

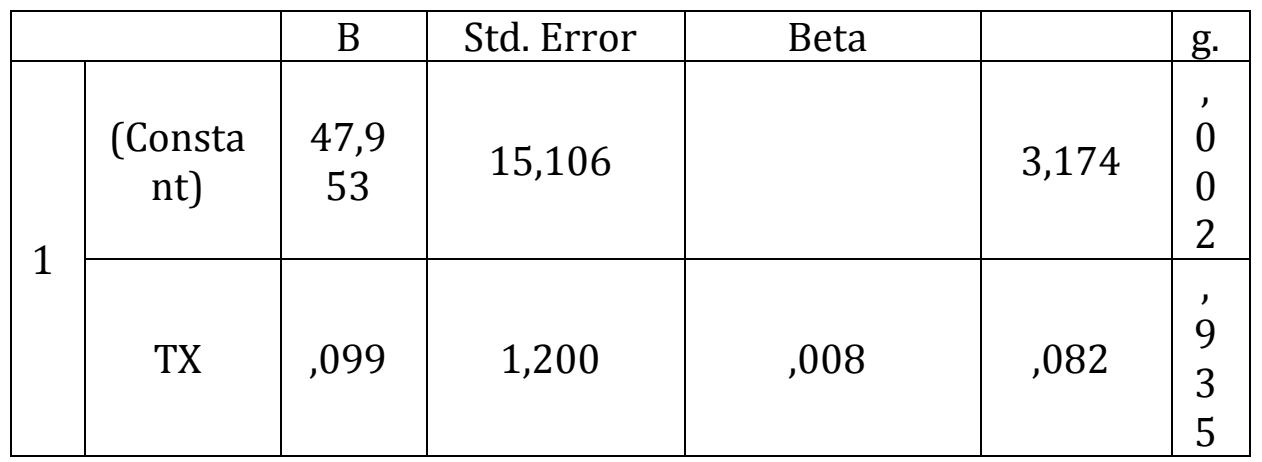

a. Dependent Variable: ABS_RES1

Pengaruh Sales Owned Loyality Terhadap Loyality to the ServiceProvider

Tabel 8.

Uji Glejser Heteroskedastisitas

\begin{tabular}{|c|c|c|c|c|c|c|}
\hline \multicolumn{7}{|c|}{ Coefficients $^{\mathbf{a}}$} \\
\hline \multirow{2}{*}{ Model } & $\begin{array}{c}\text { Unstandardized } \\
\text { Coefficients }\end{array}$ & $\begin{array}{c}\text { Standardized } \\
\text { Coefficients }\end{array}$ & \multirow{2}{*}{ t } & \multirow{2}{*}{ Sig. } \\
\cline { 2 - 6 } & B & $\begin{array}{c}\text { Std. } \\
\text { Error }\end{array}$ & Beta & & \\
\hline \multirow{2}{*}{1} & $\begin{array}{c}\text { Consta } \\
\text { nt) }\end{array}$ & $\begin{array}{c}19,3 \\
38\end{array}$ & 21,606 & &, 895 &, 373 \\
\cline { 2 - 6 } & TZ & $\begin{array}{c}1,13 \\
7\end{array}$ & 1,041 &, 110 & $\begin{array}{c}1,09 \\
2\end{array}$ &, 277 \\
\hline \multicolumn{7}{|c|}{ a. Dependent Variable: ABS_RES2 } \\
\hline
\end{tabular}

Pengaruh Sales Owned Loyality dan Loyality to the Service Provider Terhadap Word of Mouth.

Tabel 9

Uji Glejser Heteroskedastisitas

\begin{tabular}{|c|c|c|c|c|c|c|}
\hline \multicolumn{7}{|c|}{$\begin{array}{c}\text { Coefficients }^{\mathrm{a}} \\
\end{array}$} \\
\hline & \multirow{2}{*}{ Model } & \multicolumn{2}{|c|}{$\begin{array}{c}\text { Unstandardized } \\
\text { Coefficients }\end{array}$} & \multirow{2}{*}{$\begin{array}{c}\begin{array}{c}\text { Standardized } \\
\text { Coefficients }\end{array} \\
\text { Beta }\end{array}$} & \multirow{2}{*}{$\mathrm{t}$} & \multirow{2}{*}{ Sig. } \\
\hline & & B & $\begin{array}{c}\text { Std. } \\
\text { Error }\end{array}$ & & & \\
\hline \multirow{3}{*}{1} & $\begin{array}{c}\text { (Consta } \\
n t)\end{array}$ & $\begin{array}{c}41,88 \\
9\end{array}$ & 24,995 & & $\begin{array}{c}1,67 \\
6\end{array}$ & $\begin{array}{c}, 09 \\
7\end{array}$ \\
\hline & $\mathrm{TZ}$ &,- 591 & 1,286 &,- 054 &,- 460 & $\begin{array}{c}, 64 \\
7 \\
\end{array}$ \\
\hline & TLP & 1,245 & 1,520 & ,096 & ,819 & $\begin{array}{c}41 \\
5\end{array}$ \\
\hline
\end{tabular}

Berdasarkan tabel 7, 8, dan 9 diatas dapat diketahui bahwa uji glejser heteroskedastisitas dinyatakan nilai signifikan variabel independen diatas besar dari 0,05. Sehingga dapat disimpulkan bahwa tidak terjadi heteroskedastisitas dalam model ini. 
M. Riziq Agung, Ida Bagus : Membangun Word Of Mouth ....

\section{c. Uji Multikolineritas}

Uji Multikolineraritas bertujuan mengetahui hubungan atau korelasi antar variable indepden dengan denpenden. Hasil uji multikolonieritas sebagai berikut.:

\section{Pengaruh Adaptive Selling Terhadap Sales Owned Loyality Tabel 10 Uji Multikolineartias Coefficients $^{\mathbf{a}}$}

\begin{tabular}{|c|c|c|c|c|c|c|c|c|}
\hline & \multirow{2}{*}{ Model } & \multicolumn{2}{|c|}{$\begin{array}{l}\text { Unstandardized } \\
\text { Coefficients }\end{array}$} & \multirow{2}{*}{$\begin{array}{c}\begin{array}{c}\text { Standardized } \\
\text { Coefficients }\end{array} \\
\text { Beta }\end{array}$} & \multirow{2}{*}{$\mathrm{t}$} & \multirow{2}{*}{ Sig. } & \multicolumn{2}{|c|}{$\begin{array}{c}\text { Collinearity } \\
\text { Statistics }\end{array}$} \\
\hline & & B & $\begin{array}{c}\text { Std. } \\
\text { Error }\end{array}$ & & & & Tolerance & VIF \\
\hline \multirow[t]{2}{*}{1} & $\begin{array}{c}\text { (Consta } \\
\text { nt) }\end{array}$ & 11,582 & 1,159 & & 9,996 & ,000 & & \\
\hline & $\mathrm{TX}$ & ,727 & ,092 & ,624 & 7,900 & 000 & 1,000 & 1,000 \\
\hline
\end{tabular}

Berdasarkan table 10.Dapat diketahui bahwa nilai tolerance value> 0,10 atau nilai VIF $<10$ maka tidak terjadi multikolinieritas.

Pengaruh Sales Owned Loyality Terhadap Loyality to the Service Provider

Tabel 11 Uji Multikolineartias

\begin{tabular}{|c|c|c|c|c|c|c|c|c|}
\hline & \multicolumn{8}{|c|}{ Coefficients } \\
\hline & \multirow{2}{*}{ Model } & \multicolumn{2}{|c|}{$\begin{array}{l}\text { Unstandardized } \\
\text { Coefficients }\end{array}$} & \multirow{2}{*}{$\begin{array}{c}\begin{array}{c}\text { Standardized } \\
\text { Coefficients }\end{array} \\
\text { Beta }\end{array}$} & \multirow{2}{*}{$\mathrm{T}$} & \multirow{2}{*}{ Sig. } & \multicolumn{2}{|c|}{$\begin{array}{l}\text { Collinearity } \\
\text { Statistics }\end{array}$} \\
\hline & & B & $\begin{array}{l}\text { Std. } \\
\text { Error }\end{array}$ & & & & $\begin{array}{c}\text { Toleran } \\
\text { ce }\end{array}$ & VIF \\
\hline \multirow{2}{*}{1} & (Constant) & 6,519 & 1,525 & & $\begin{array}{c}4,27 \\
5\end{array}$ & $\begin{array}{c}, 00 \\
0\end{array}$ & & \\
\hline & $\mathrm{TZ}$ & ,431 & 073 & ,510 & $\begin{array}{c}5,87 \\
0\end{array}$ & $\begin{array}{c}00 \\
0\end{array}$ & 1,000 & 1,000 \\
\hline
\end{tabular}

Berdasarkan table 11 Dapat diketahui bahwa nilai tolerance value> 0,10 atau nilai VIF $<10$ sehingga tidak terjadi multikolinieritas.

Pengaruh Sales Owned Loyality dan Loyality to the Service Provider Terhadap Word of Mouth

Tabel 12 Uji Multikolineartias

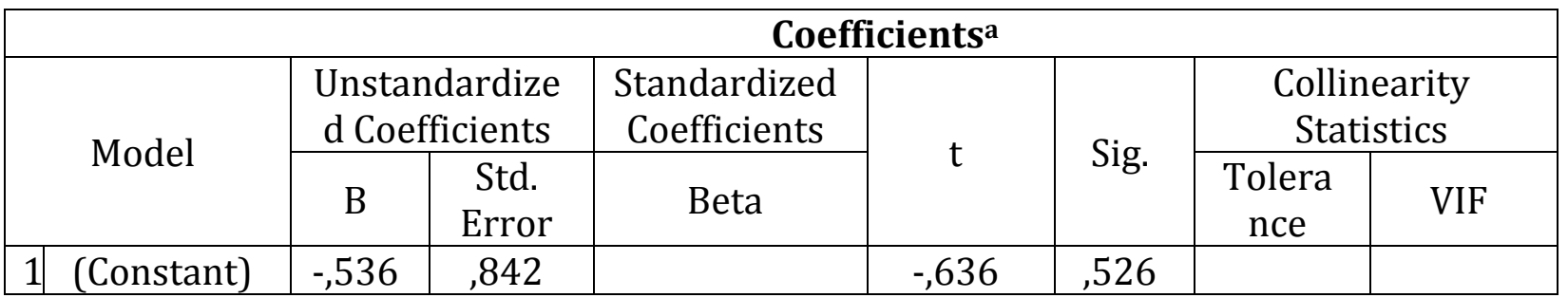




\begin{tabular}{|c|c|c|c|c|c|c|c|c|}
\hline & TZ &, 248 &, 043 &, 477 & 5,729 &, 000 &, 740 & 1,352 \\
\cline { 2 - 7 } & TLP &, 205 &, 051 &, 334 & 4,005 &, 000 &, 740 & 1,352 \\
\hline \multicolumn{7}{|c|}{ a. Dependent Variable: TWOM } \\
\hline
\end{tabular}

Berdasarkan tabel 12 diketahui bahwa nilai tolerance value $>0,10$ atau nilai VIF $<10$ sehingga tidak terjadi multikolinieritas

\section{Analisis Regresi}

Dalam model analisis regresi akan dilakukan analisis uji t (lampiran 3) dan akan menunjukkan koefisien $(\beta)$ untuk masing-masing variable. Dapat diketahui nilai dari koefisien konstanta adalah 11,582koefisien Adaptiveselling 0,624, sehingga diperoleh persamaan SL $=11,582+0,624 \mathrm{AS}+\mathrm{e}$. Nilai dari koefisien konstanta adalah 6,519 koefisien Salesperson Ownde loyalty 0, ,510, sehingga diperoleh persamaan sebagai berikut LSP $=6,519+0,510 S L+e$. Koefisien konstanta ,536 dengan Salesperson Ownde loyalty 0,477 koefisien Loyality To The Service Provider 0,334 sehingga diperoleh persamaan $\mathrm{WOM}=-536+0,477 \mathrm{SL}+0,334 \mathrm{LSP}+\mathrm{e}$.

4. Uji Hipotesis

\section{a. Uji Signifikan Individu (Uji Statistik t)}

Uji statistik (uji t) dimaksudkan untuk menunjukkan seberapa jauh pengaruh satu variabel independen secara individual menerangkan variasi variabel dependen. Diketahui rumus t- tabel yaitu t tabel $(\mathrm{df}=100-2, \mathrm{df}=98)$ sehingga diketahui t- tabel adalah 1,66055.

Pengaruh Adaptive Selling Terhadap Sales Owned Loyality

Tabel 13Hasil Analisis Uji t

\begin{tabular}{|c|c|c|c|c|c|c|}
\hline \multicolumn{2}{|c|}{ Coefficients $^{\mathbf{a}}$} \\
\hline \multirow{2}{*}{ Model } & \multicolumn{2}{c|}{$\begin{array}{c}\text { Unstandardized } \\
\text { Coefficients }\end{array}$} & $\begin{array}{c}\text { Standardized } \\
\text { Coefficients }\end{array}$ & \multicolumn{2}{c|}{$\mathrm{t}$} & Sig. \\
\cline { 2 - 7 } & $\mathrm{B}$ & Std. Error & Beta & & \\
\hline \multirow{3}{*}{1} & $\begin{array}{c}\text { Constant } \\
\text { B }\end{array}$ & 11,582 & 1,159 & & 9,996 &, 000 \\
\cline { 2 - 7 } & TX &, 727 &, 092 &, 624 & $\begin{array}{c}7,90 \\
0\end{array}$ &, 000 \\
\hline \multicolumn{7}{|c|}{ a. Dependent Variable: TZ } \\
\hline
\end{tabular}

Pengaruh Sales Owned Loyality Terhadap Loyality to the Service Provider Tabel 14 Hasil Analisis Uji t

\begin{tabular}{|c|c|c|c|c|c|c|}
\hline \multicolumn{7}{|c|}{ Coefficients $^{a}$} \\
\hline \multirow{2}{*}{\multicolumn{2}{|c|}{ Model }} & \multicolumn{2}{|c|}{$\begin{array}{l}\text { Unstandardized } \\
\text { Coefficients }\end{array}$} & \multirow{2}{*}{$\begin{array}{c}\begin{array}{c}\text { Standardize } \\
\mathrm{d} \\
\text { Coefficients }\end{array} \\
\text { Beta }\end{array}$} & \multirow[t]{2}{*}{$\mathrm{t}$} & \multirow[t]{2}{*}{ Sig. } \\
\hline & & B & Std. Error & & & \\
\hline \multirow{2}{*}{1} & $\begin{array}{c}\text { (Consta } \\
n t)\end{array}$ & 6,519 & 1,525 & & $\begin{array}{c}4,27 \\
5\end{array}$ & $\begin{array}{c}, 00 \\
0\end{array}$ \\
\hline & $\mathrm{TZ}$ & ,431 & ,073 & ,510 & $\begin{array}{c}5,87 \\
0\end{array}$ & $\begin{array}{c}00 \\
0\end{array}$ \\
\hline
\end{tabular}

a. Dependent Variable: TLP

Pengaruh Sales Owned Loyality dan Loyality to the Service Provider Terhadap Word of Mouth 
M. Riziq Agung, Ida Bagus : Membangun Word Of Mouth ....

Tabel 15 Hasil Analisis Uji t

\begin{tabular}{|c|c|c|c|c|c|c|}
\hline \multicolumn{7}{|c|}{ Coefficients $^{a}$} \\
\hline \multirow{2}{*}{\multicolumn{2}{|c|}{ Model }} & \multicolumn{2}{|c|}{$\begin{array}{l}\text { Unstandardized } \\
\text { Coefficients }\end{array}$} & \multirow{2}{*}{$\begin{array}{c}\begin{array}{c}\text { Standardize } \\
\mathrm{d} \\
\text { Coefficients }\end{array} \\
\text { Beta }\end{array}$} & \multirow[t]{2}{*}{$\mathrm{t}$} & \multirow[t]{2}{*}{ Sig. } \\
\hline & & B & Std. Error & & & \\
\hline \multirow{3}{*}{1} & $\begin{array}{c}\text { (Consta } \\
\text { nt) }\end{array}$ &,- 536 & ,842 & & $\begin{array}{c}- \\
, 636 \\
\end{array}$ & ,526 \\
\hline & $\mathrm{TZ}$ & ,248 &, 043 & ,477 & $\begin{array}{c}5,72 \\
9\end{array}$ & 000 \\
\hline & TLP & 205 & 051 & ,334 & $\begin{array}{c}4,00 \\
5\end{array}$ & 000 \\
\hline \multicolumn{7}{|c|}{ a. Dependent Variable: TWOM } \\
\hline
\end{tabular}

Hasil Uji t nilai sig. Dapat disimpulkan hasil uji t sebagai berikut :

1) i Berdasarkan tabel $4.18 \mathrm{di}$ atas dapat diketahui hasil pengujian signifikansi menunjukkan bahwa terdapat nilai probabilitas sebesar $0.000(0,000 \leq 0,05)$. Nilai tersebut dapat membuktikan $\mathrm{Ha}_{1}$ diterima, yang berarti bahwa "Adaptiveselling berpengaruh positif terhadap Salesperson Ownde loyalty".

2) ii Berdasarkan tabel 4.19 di atas dapat diketahui hasil pengujian signifikansi menunjukkan bahwa terdapat nilai probabilitas sebesar $0.000(0,000 \leq 0,05)$. Nilai tersebut dapat membuktikan $\mathrm{Ha}_{2}$ diterima, yang berarti bahwa "Salesperson Ownde loyalty berpengaruh positif terhadap Loyality To The Service Provider".

3) iii Berdasarkan tabel 4.20 di atas dapat diketahui hasil pengujian signifikansi menunjukkan bahwa terdapat nilai probabilitas sebesar $0.000(0,000 \leq 0,05)$. Nilai tersebut dapat membuktikan $\mathrm{Ha}_{3}$ diterima, yang berarti bahwa "Salesperson Ownde loyalty berpengaruh positif terhadap Word Of Mouth".

4) iv Berdasarkan tabel 4.19 di atas dapat diketahui hasil pengujian signifikansi menunjukkan bahwa terdapat nilai probabilitas dengan besar $0,000(0,000 \leq 0,05)$. Nilai tersebut dapat membuktikan $\mathrm{Ha}_{4}$ diterima, yang berarti bahwa "Loyality To The Service Providerberpengaruh positif terhadap Word Of Mouth".

b. Koefisien Determinasi (Adjusted R2)

Pengaruh Adaptive Selling Terhadap Sales Owned Loyality

Tabel 16

Hasil Analisis Koefisien Determinasi

\begin{tabular}{|c|c|c|c|c|}
\hline \multicolumn{5}{|c|}{ Model Summary } \\
\hline Model & $\mathrm{R}$ & $\begin{array}{c}\mathrm{R} \\
\text { Square }\end{array}$ & $\begin{array}{c}\text { Adjusted R } \\
\text { Square }\end{array}$ & $\begin{array}{c}\text { Std. Error of the } \\
\text { Estimate }\end{array}$ \\
\hline 1 &, $624^{\mathrm{a}}$ &, 389 &, 383 & 1,9045 \\
\hline
\end{tabular}

a. Predictors: (Constant), TX

b. Dependent Variable: TZ 
M. Riziq Agung, Ida Bagus : Membangun Word Of Mouth ....

\section{Pengaruh Sales Owned Loyality Terhadap Loyality to the Service Provider Tabel 4. 17 \\ Hasil Analisis Koefisien Determinasi

\begin{tabular}{|c|c|c|c|c|}
\hline \multicolumn{5}{|c|}{ Model Summary } \\
\hline $\begin{array}{c}\text { Mod } \\
\text { el }\end{array}$ & $\mathrm{R}$ & $\begin{array}{c}\mathrm{R} \\
\text { Square }\end{array}$ & $\begin{array}{c}\text { Adjusted R } \\
\text { Square }\end{array}$ & $\begin{array}{c}\text { Std. Error } \\
\text { of the } \\
\text { Estimate }\end{array}$ \\
\hline 1 &, $510^{\mathrm{a}}$ &, 260 &, 253 & 1,7726 \\
\hline \multicolumn{5}{|c|}{ a. Predictors: (Constant), TZ } \\
\hline \multicolumn{5}{|c|}{ b. Dependent Variable: TLP } \\
\hline
\end{tabular}

\section{Pengaruh Sales Owned Loyality dan Loyality to the Service Provider Terhadap Word of Mouth}

Tabel 18

Hasil Analisis Koefisien Determinasi

\begin{tabular}{|c|c|c|c|c|}
\hline \multicolumn{5}{|c|}{ Model Summary } \\
\hline $\begin{array}{c}\text { Mod } \\
\text { el }\end{array}$ & $\mathrm{R}$ & $\begin{array}{c}\mathrm{R} \\
\text { Square }\end{array}$ & $\begin{array}{c}\text { Adjusted R } \\
\text { Square }\end{array}$ & $\begin{array}{c}\text { Std. Error } \\
\text { of the } \\
\text { Estimate }\end{array}$ \\
\hline 1 &, $708^{\mathrm{a}}$ &, 502 &, 491 &, 8987 \\
\hline \multicolumn{5}{|c|}{ a. Predictors: (Constant), TLP, TZ } \\
\hline \multicolumn{4}{|c|}{ b. Dependent Variable: TWOM } \\
\hline
\end{tabular}

Berdasarkan tabel 17 dan 18 menunjukkan besarnya koefisien determinasi (Adjusted $R^{2}$ ) $=0,383$, artinya variabel bebas secara bersamasama mempengaruhi variabel terikat sebesar 38,3\% sisanya sebesar $61,7 \%$ disebabkan oleh variabel lain yang tidak dimasukkan dalam model penelitian

Berdasarkan tabel 4.22 menunjukkan besarnya koefisien determinasi (Adjusted $R^{2}$ ) = 0,253, artinya variabel bebas secara bersama-sama mempengaruhi variabel terikat sebesar 25,3\% sisanya sebesar 74,7\% disebabkan oleh variabel lain yang tidak dimasukkan dalam model penelitian.

Berdasarkan tabel 4.23 menunjukkan besarnya koefisien determinasi (Adjusted $R^{2}$ ) = 0,491, artinya variabel bebas secara bersama-sama mempengaruhi variabel terikat sebesar 49,1\% sisanya sebesar 50,9\% disebabkan oleh variabel lain yang tidak dimasukkan dalam model penelitian.

\section{Pembahasan}

\section{a. Pengaruh Adaptive SallingTerhadap Custumer owned loyalty}

Berdasarkan Hasil analisis data menunjukkan bahwa Adaptive Salling berpengaruh positif terhadap Owned Loyalty. Hal tersebut terbukti dengan nilai koefisien ( $\beta$ ) sebesar 0.624 dengan probabilitas 0,000 dimana angka tersebut signifikan karena $(\mathrm{p}<0,05)$. Hal ini berdasarkan dengan penelitian yang dilakukan oleh Castleberry \& Shepperd ${ }^{16}$ bahwa menunjukkan hubungan yang positif antara adaptive selling dengan kinerja penjualan.

\footnotetext{
${ }^{16}$ Castleberry, S. B., C. David Shepherd, \& Rick, R. Effective Interpersonal Listening in the Personal Selling Environment: Conceptualization, Measurement, and Nomological Validity, 1999), h. 89-90
} 


\section{b. Pengaruh Custumer owned loyaltyTerhadap loyalty To The Service Proveder}

Berdasarkan Hasil analisis data menunjukkan bahwa Custumer owned loyaltyberpengaruh positif terhadaployalty To The Service Proveder. Hal tersebut terbukti dengan nilai koefisien $(\beta)$ sebesar 0.510 dengan probabilitas 0,000 dimana angka tersebut signifikan karena $(\mathrm{p}<0,05)$.

Hal ini berdasarkan dengan penelitian yang dilakukan oleh Farida Jasfar ${ }^{17}$ bahwa ada dampak positif antara kualitas jasa dengan loyalitas. Diduga kualitas pelayanan berdampak positif dan signifikan terhadap loyalitas nasabah.

\section{c. Pengaruh Custumer owned loyaltyTerhadap Word Of Mouth}

Berdasarkan Hasil analisis data menunjukkan bahwa Custumer owned loyaltyberpengaruh positif terhadap Word of Mouth. Hal tersebut terbukti dengan nilai koefisien $(\beta)$ sebesar 0.477 dengan probabilitas 0,000 dimana angka tersebut signifikan karena $(\mathrm{p}<0,05)$. Hal ini berdasarkan dengan penelitian yang dilakukan oleh Ardanii dan Suprapti ${ }^{18}$ bahwa kualitas layanan berdampak positif dan signifikan terhadap word of mouth (WOM).

\section{d. Pengaruh Loyalty To The Service ProviderTerhadap Word Of Mouth}

Berdasarkan Hasil analisis data menunjukkan bahwa Kualitas Produk memberi dampak positif terhadap Loyalitas Pelanggan. Hal tersebut terbukti dengan nilai koefisien $(\beta)$ sebesar 0.334 dengan probabilitas 0,000 dimana angka tersebut signifikan karena $(\mathrm{p}<0,05)$. Hal ini berdasarkan dengan penelitian yang dilakukan oleh Yuli Rahmawati dan Bagus Suminar ${ }^{19}$ bahwa variabel loyalitas pelanggan memiliki pengaruh yang signifikan positif terhadap word of mouth.

\section{E. Penutup}

1. Simpulan

a. Variabel Adaptive sellingberpengaruh positif terhadap Custumer owned loyalty berdasarkan uji t mendapatkan t hitung sebesar 7,900 dengan nilai signifikansi $0,000<0,05$. Hasil penelitian menunjukan hipotesis pertama diterima, hal ini karena Tenaga penjual akan dapat memberikan suatu pemuasan kebutuhan pada pelanggan karena mampu mengenali setiap kebutuhan dan keinginan pelanggan yang berbeda karena mampu mengenali setiap kebutuhan dan keinginan pelanggan yang berbeda-beda dan memberikan suatu alternative pendekatan penjualan yang tepat. Pada akhirnya adaptif selling ini akan meningkatkan kinerja penjualan yang dicapai tenaga penjual.

b. Variabel Custumer owned loyalty berpengaruh positif terhadapLoyalty to the Service Provider berdasarkan hasil uji t mendapatkan t hitung sebesar 5,870 dengan nilai signifikansi $0,000<0,05$. Hasil penelitian menunjukan hipotesis kedua diterima, sehingga semakin tinggi loyalitas pelayanan yang diberikan membuat pelanggan loyal terhadap produk atau jasa yang dikeluarkan oleh perusahaan. Hal tersebut terjadi karena pelanggan memiliki presepsi bahwa mereka diberikan layanan yang terbaik baik, hal ini yang menimbulkan rasa puas dan loyal terhadap perusahaan tersebut.

\footnotetext{
${ }^{17}$ Jasfar, Farida. Teori dan Aplikasi Sembilan Kunci Keberhasilan Bisnis Jasa: Sumber Daya Manusia, Inovasi, Dan Kepuasan Pelanggan, 2002), h.67

${ }^{18}$ Ardani, Wayan dan Ni Wayan Sri Suprapti. Pengaruh Kualitas Pelayanan Terhadap Kepuasan dan WOM (Pada RSUD Wangaya Denpasar), 2008), h.4

${ }^{19}$ Rahmawati, Yuli dan Bagus Suminar. Pengaruh Kepuasan dan Loyalitas Pelanggan Terhadap Word Of Mouth pada Pelanggan Honda Motor di Surabaya, 2014), h. 5
} 
c. Variabel Custumer owned loyalty berpengaruh positif terhadap Word of Mouthberdasarkan hasil uji t mendapatkan t hitung sebesar 5,729 dengan nilai signifikansi $0,000<0,05$. Hasil penelitian menunjukan hipotesis ketiga diterima. Loyalitas pelayanan yaitu salah satu elemen penting yang menjadi pertimbangan bagi pelanggan yang melakukan pembelian suatu produk. Pelayanan dengan pendekatan word of mouth menurut Hasan ${ }^{20}$ merupakan bagian dari strategi promosi dalam kegiatan pemasaran yang menggunakan orang ke orang yang puas untuk meningkatkan kesadaran produk dan menghasilkan tingkat penjualan tertentu dengan tujuan membentuk word of mouth perusahaan perlu membangun hubungan yang lebih dekat dengan konsumennya.

d. Variabel Loyalty to the Service Provider berpengaruh positif terhadap Word of Mouth berdasarkan hasil uji t mendapatkan t hitung sebesar 4,005 dengan nilai signifikansi $0,000<0,05$. Hasil penelitian menunjukan hipotesis keempat diterima. Komunikasi dari mulut ke mulut dapat dijadikan sebagai kekuatan bagi konsumen yang puas maupun konsumen yang tidak puas. Konsumen yang puas cenderung menghasilkan komunikasi dari mulut ke mulut secara positif. Kepuasan konsumen seringkali dikaitkan dengan evaluasi yang menyeluruh dari konsumen yang cenderung dapat berdampak atau mempengaruhi perilaku konsumen terhadap kualitas jasa atau produk sehingga dapat membantu perusahaan berupa komunikasi dari mulut ke mulut yang positif.

\section{Daftar Pustaka}

Agus, Sulastiyono. (2011). Manajemen Penyelanggaraan Hotel. Bandung: Alfabeta.

Anglin A. K., Stolman, J.J. \& Gentry, J.W. 1990. The congruence of manager perception of salesperson performance and knowledge-Based measure of adaptive selling. Journal of personal selling \& sales management Vol.10: 81-90

Arbaniah, Siti (2010). Studi Customer Loyalty (WOM) Positif Pada Bisnis Ritel Pasar Modern. Semarang.

Ardani, Wayan dan Ni Wayan Sri Suprapti. 2012. Pengaruh Kualitas Pelayanan Terhadap Kepuasan dan WOM (Pada RSUD Wangaya Denpasar). EJurnal Manajemen Universitas Udayana.Vol.1 No.2

Assael, Henry. 1998. Customer behavior and marketing action, fifth edition. Salemba empat-prentice hall

Castleberry, S. B., C. David Shepherd, \& Rick, R. (1999). Effective Interpersonal Listening in the Personal Selling Environment: Conceptualization, Measurement, and Nomological Validity. Journal of Marketing Theory \& Practic, 7 (1), hal.30-38.

Chen, Z. X. and Francesco, A. M. (2014) 'Employee demography, organizational commitment, and turnover intentions in China: Do cultural differences matter?', Human Relations, 53(6), pp. 869-887. doi: 10.1177/0018726700536005.

${ }^{20}$ Hasan, Ali. Marketing dari Mulut ke Mulut (Word of Mouth Marketing), 2011), h.3 
Goyette, I., Ricard, L., Bergeron, J., and François Marticotte. 2010. e-WOM Scale: Word-ofMouth Measurement Scale for e-Services Context. Canadian Journal of Administrative Sciences.

Griffin, J. (2005). Customer Loyalty: Menumbuhkan dan Mempertahankan Kesetiaan Pelanggan. Diterjemahkan oleh: Dwi Kartini Yahya. Jakarta: Erlangga

Hasan, Ali. (2010). Marketing dari Mulut ke Mulut (Word of Mouth Marketing). Yogyakarta: Media Press.

Hasan , Ali. 2014. Marketing dan kasus-kasus Pilihan, Cetakan Kedua. Yogyakarta. CAPS (Center for Academic Publishing Service).

Huriyati, Ratih. 2005. Bauran Pemasaran Dan Loyalitas Konsumen. Bandung: Alfabeta.

Huryati, R. 2008. Bauran Pemasaran dan Loyalitas Konsumen. Edisi Kedua. Bandung: CV. Alfabeta.

Jasfar, Farida. Teori dan Aplikasi Sembilan Kunci Keberhasilan Bisnis Jasa: Sumber Daya Manusia, Inovasi, Dan Kepuasan Pelanggan. Jakarta: Salemba Empat, 2012.

Kotler, Amstrong (2004). Prinsip-prinsip Pemasaran, Erlangga, Jakarta.

Kotler dan Keller. 2007. Manajemen Pemasaran, Jilid 1, Edisi 12. Jakarta. Indeks.

Kotler, Philip. 2008. Prinsip-Prinsip Pemasaran. Edisi 12. Alih Bahasa: Bob Sabran . Jakarta: Erlangga.

Lovelock, C., \& Wirtz, J. (2011). Service Marketing: People, Technology, Strategy 7th Edition. New Jersey: Prentice Hall.

Lupiyoadi dan Hamdani, 2006. Manajemen Pemasaran jasa Edisi kedua. Penerbit Salemba Empat: Jakarta.

Malau, Harman. 2017. Manajememn Pemasaran. CV Alfabeta. Bandung.

Morgan, C.T., King, R.A., Weisz, J.R., \&Schopler.(1986). Introduction to psychology (7th ed.). Singapore: McGraw-Hill,inc.

Nugroho, Farid Yuniar. 2011. Pengaruh Citra Merek dan Kepuasan Pelanggan Terhadap Loyalitas Konsumen. Yogyakarta: Fakultas Pertanian Universitas Pembangunan Nasional "Veteran".

Oliver, Richard, 1993. A Coceptual Model Of Service Quality and Service Satisfaction; Compatibe Goal, Different Concept,in advance in Service Marketing and management vol 2; $p 65-85$

Rahmawati, Yuli dan Bagus Suminar. 2014. "Pengaruh Kepuasan dan Loyalitas Pelanggan Terhadap Word Of Mouth pada Pelanggan Honda Motor di Surabaya". Jurnal Administrasi Bisnis. Vol. 4, No. 1, Mei 2014. Hal 15-30.

Rangkuti, Freddy. (2009). Mengukur Efektivitas Program Promosi \& Analisis Kasus Menggunakan SPSS. Jakarta: PT Gramedia Pustaka Utama. 
Román, Sergio, and Dawn Iacobucci. 2010. "Antecedents and Consequences of Adaptive Selling Confidence and Behavior:A Dyadic Anaysis Salespeople and their Customers."Journal of the Academy of Marketing Science 38 (3): 363-382. doi:10.1007/s11747-009-0166-9.

Sernovitz, Andy. (2009). Word of mouth Marketing. New York: Kaplan Inc

Sugiyono. 2013. Metode Penelitian Pendidikan Pendekatan Kuantitatif, Kualitatif, dan R\&D. Bandung: Alfabeta.

Sujan et al. 1994. “ Learning Orientation, Working, and Efective Selling”, Journal Marketing, Vol. 58, July 39-52

Sumarwan, U. (2011). Perilaku Konsumen: Teori dan Penerapan dalam Pemasaran, Jakarta: Ghalia Indonesia.

Sumardy, dkk., 2011. The Power of Word of Mouth Marketing. Jakarta. Gramedia Pustaka Utama.

Sunyoto, Danang .2012. konsep Dasar Riset Pemasaran dan Perilaku Konsumen, Cetakan Pertama. Yogyakarta . CAPS(Center for Academic Publishing Service)

Supranto, dan Limakrisna, Nandan. 2011. Perilaku Konsumen dan Strategi Pemasaran, Edisi Kedua. Jakarta. Mitra Wacana Media.

Tjiptono, Fandy dan Chandra, Gregorius. 2011. Service, Quality, andSatisfaction, edisi pertama. Yogyakarta :Andi Offset.

Weitz, A.A. Sujan, H., \& Sujan, M, 1986. Knowladge, Motivation, Adaptive Behavior. A Framework for Improving Selling Effectiveness. Journal of Marketing Vol. 50:174191

Weitz, B.A., Sujan, H., \& Sujan, M. 1986. Knowledge, Motivation, Adaptive Behaviour: A Framework for Improving Selling Effectiveness. Journal of Marketing. Vol. 50: 174191

Weitz, Barton A., Harish Sujan, and Mita Sujan. 1986. "Knowledge, Motivation, and Adaptive Behaviour: A Framework for Improving Selling Effectiveness." Journal of Marketing 50 (4): 174-191. doi:10.2307/1251294. 